\title{
ROLE OF PSYCHOLOGICAL AND PEDAGOGICAL SUPPORT IN THE LIFE OF PEOPLE WITH DISABILITIES
}

\author{
ANNA ZIĘTEK
}

\begin{abstract}
The paper presents the essence and needs of support in the lives of people with disabilities. It shows that in order to adapt support to the individual needs of people with disabilities it is necessary to introduce elements improving the aid system. It indicates the tasks and importance of factors of the system supporting people with disabilities individually and in the social and professional environment. Legislative solutions in force were presented, which are aimed at stimulating professional activity and integrating disabled people and their families into the environment. The paper offers solutions to improve the system of equalization of opportunities in social and professional life of people with special needs. The importance of supporting professional activity and employment in the labour market was discussed. An attempt was made to assess the factors determining the effectiveness of the system, taking into account the implemented aid programs, grants, benefits and tasks of organizations and institutions supporting people with disabilities in social and professional life. The importance of integration, family support, support of the environment as well as adaptation of the system to the needs of people with disabilities was presented. Among the listed factors relating to people with disabilities, the importance of preparation, professional development and adaptation to the open labour market was presented. The social perception of disability is also of particular importance, which, if properly shaped, can reduce the problem of functioning of people with disabilities in social and professional life. People with disabilities show differing levels of need for safety, independence or accessibility to social infrastructure. This diversity depends on the support of families of people with disabilities, their caregivers and aid institutions and organizations, including those providing education, rehabilitation and vocational activity services. The paper presents activities, which are the starting point for looking for new solutions and improving current solutions for adapting support to the individual needs of people with disabilities.
\end{abstract}

Keywords: professional training, education, professional activity, labor market, vocational training, persons with disabilities, psychological and pedagogical support of people with disabilities.

\section{INTRODUCTION}

Need is a driving force behind acting. It stems from a sense of insecurity, lack of group belonging, social contacts, recognition and other important necessities in our lives. In economic theory, it is the state of feeling unsatisfied [14, p. 7], which is an important factor that makes dynamic human behaviour [25, p. 40]. In pedagogical fields, the need is defined in a similar way, as a desire to satisfy a 
lack accompanied by a strong motivation [23, p. 29]. The need directed towards different objects is satisfied in a way that depends on the psychophysical and intellectual properties of each person [6, p. 86]. K. M. Czarnecki states that satisfying the intellectual needs of the society concerns, among others, its professional development in various fields, conditions and situations [5, p. 17]. The needs seen in the context of professional development can be perceived as an encouragement to act in a certain direction, and the profession or its choice is a pillar of the decision in meeting them [25, p. 55]. Therefore, the process of professional development, which is a sequence of changes occurring in the consciousness and behaviour of the individual [4, p. 166], requires support at every stage of the decision. The support provided can be a factor in the likelihood of meeting needs as well as in identifying them properly, which in the case of people with disabilities is of great importance. According to the literature on the subject, the needs of people with disabilities are most often related to:

- sense of self-esteem, which in consequence, after satisfying this need, stimulates to activity in social and professional life [18, p. 56];

- acceptance, or the right attitude towards disability, of oneself and other people [9, p. 106];

- social support, which leads to proper perception of people with disabilities and their families [31, p. 157];

- health issues related to care, treatment and access to rehabilitation [33, p. 223];

- emotional support, especially to be listened to, understood and helped in the process of reducing anxiety [16, p. 267];

- the functioning of systemic solutions concerning accessibility to individual programmes preparing people with disabilities for vocational education and coping in the labour market [39, p. 353];

independent functioning, especially social and professional integration, rehabilitation, education and work [1, p. 86].

\section{ESSENCE AND NEEDS OF SUPPORT}

The needs of social and professional life may differ depending on the type of disability, category of intensity, and in particular from the support received, which is defined as assistance in difficult situations or material and moral assistance provided to a person in need [29, p. 680]. For people with disabilities, support is often the main element in meeting the needs of affiliation, which can vary in intensity and difficulty. The need for affiliation may be limited in scope and capacity, therefore the ways to satisfy it are often complementary and substitutive [14, p. 11]. The various ways in which people with disabilities meet their needs independently are supported or replaced by social or professional impact and cooperation defined as activities carried out together or in agreement, as well as assistance and participation in joint work [4, p. 205]. Assistance to people with disabilities involves cooperation with them through various forms of support, such as emotional, informational, material, spiritual and social support, understood as meeting social needs through interaction with significant people, which strengthens the sense of belonging, security and approval [31, p. 145].

It can therefore be assumed that support aimed at achieving and maintaining the highest possible quality of life is of particular importance in meeting the needs of people with disabilities [23, p. 31]. Support, commonly referred to as aid, is an integral part of life [13, p. 16]. People with disabilities generally expect informational, material and financial support; in the personal field, they require moral and spiritual aid. This social support is often a motivator for changes in attitude, behaviour, decisions or overcoming important professional and life difficulties. They receive social support because of their social bonds. Often it is support from reference groups appropriate to their respective roles. The most expected is the support from family, people from close surroundings and the local environment. The family is the foundation of life and shapes personality traits that affect the professional development and attitudes and behaviours of its members [25, p. 217]. It affects vocational education, preparation for professional work, one's own activity, interest in the profession, as well as integration with the environment [25, p. 336]. The value of the family in the life of people with disabilities is emphasized by the literature on the subject, which additionally indicates the importance of assistance and support for 
the family in the following areas: financial and material assistance, assistance in removing architectural barriers, purchasing equipment, assistance in undertaking treatment and rehabilitation, undertaking education and psychological assistance in the education and work system [12, p. 7]. It follows from legislative documents that families of disabled people can receive the above-mentioned aid or support in the form of:

- co-financing of the costs of the stay of disabled people in Occupational Therapy Workshops [38];

- care services for parents of disabled children and care services for the disabled. Financial benefits in families raising a disabled child under the 500+ programme [38];

- co-financing of rehabilitation holidays [27];

- benefit or pre-retirement benefit entitlement for former carers of disabled people who have lost the right to a nursing allowance,

- special carer's allowance or a guardian's allowance due to the death of the disabled person they were caring for. Subsidies for rehabilitation equipment [28];

- elimination of architectural barriers and communication barriers [26];

- using tax deductions as part of rehabilitation relief [36].

Forms of assistance and support in achieving independence of people with disabilities include:

- elimination of barriers to the professional and social activity of people with disabilities,

- preparation of educational programmes and projects, as well as projects increasing the economic activity of people with disabilities in the labour market [30, p. 310] and the frequency of their employment,

- adjusting the education system of these people by facilitating their access to vocational and continuing education [20, p. 87-94].

Existing legislative solutions aim to integrate people with disabilities and their families into the environment and to equalise their opportunities in social and professional life. In addition, the Act of 27 August 1997 on Vocational and Social Rehabilitation and Employment of Disabled People [37], provides support for the disabled in their professional activity and employment in the labour market. In these activities, people with disabilities are supported by Occupational Therapy Workshops, in Occupational Activation Centres, Protected Employment Centres and also in County Labour Offices, inter alia, through the possibility of obtaining employment or restoring skills necessary to take up employment [37].

A detailed approach to the proposed support is presented in Figure 1, which shows that a solution important for people with disabilities are tasks in the field of employment promotion, mitigating the effects of unemployment and professional activation implemented by labour market institutions [35]. In addition, the activities shown in the figure can be a starting point for finding further solutions for adapting support to the individual needs of people with disabilities. The consequence of the proposed tasks should be to meet needs that vary greatly depending on the type of disability. People with disabilities show differing levels of need for safety, independence or accessibility to social infrastructure. This diversity depends on the support of families of people with disabilities, their caregivers and aid institutions and organisations, including those providing education, rehabilitation and vocational activity services. The social perception of disability is also of particular importance, which, if properly shaped, can reduce the problem of functioning of people with disabilities in social and professional life. It can also make a strong contribution to meeting the basic needs of people with disabilities and their families.

According to the Act of 20 April 2004 on Employment Promotion and Market Institutions, special programmes are also created, the aim of which is to help people with disabilities to adapt their qualifications or acquire new ones, as well as financial support or elimination of barriers hindering active life [35]. Particularly noteworthy are the programs subsidised under the tasks of the State Fund for the Rehabilitation of People with Disabilities (Pol. PFRON), which are looking for new systemic solutions in their own tasks. The State Fund for the Rehabilitation of the Disabled co-finances programmes to support people with disabilities in vocational and social rehabilitation and programmes 


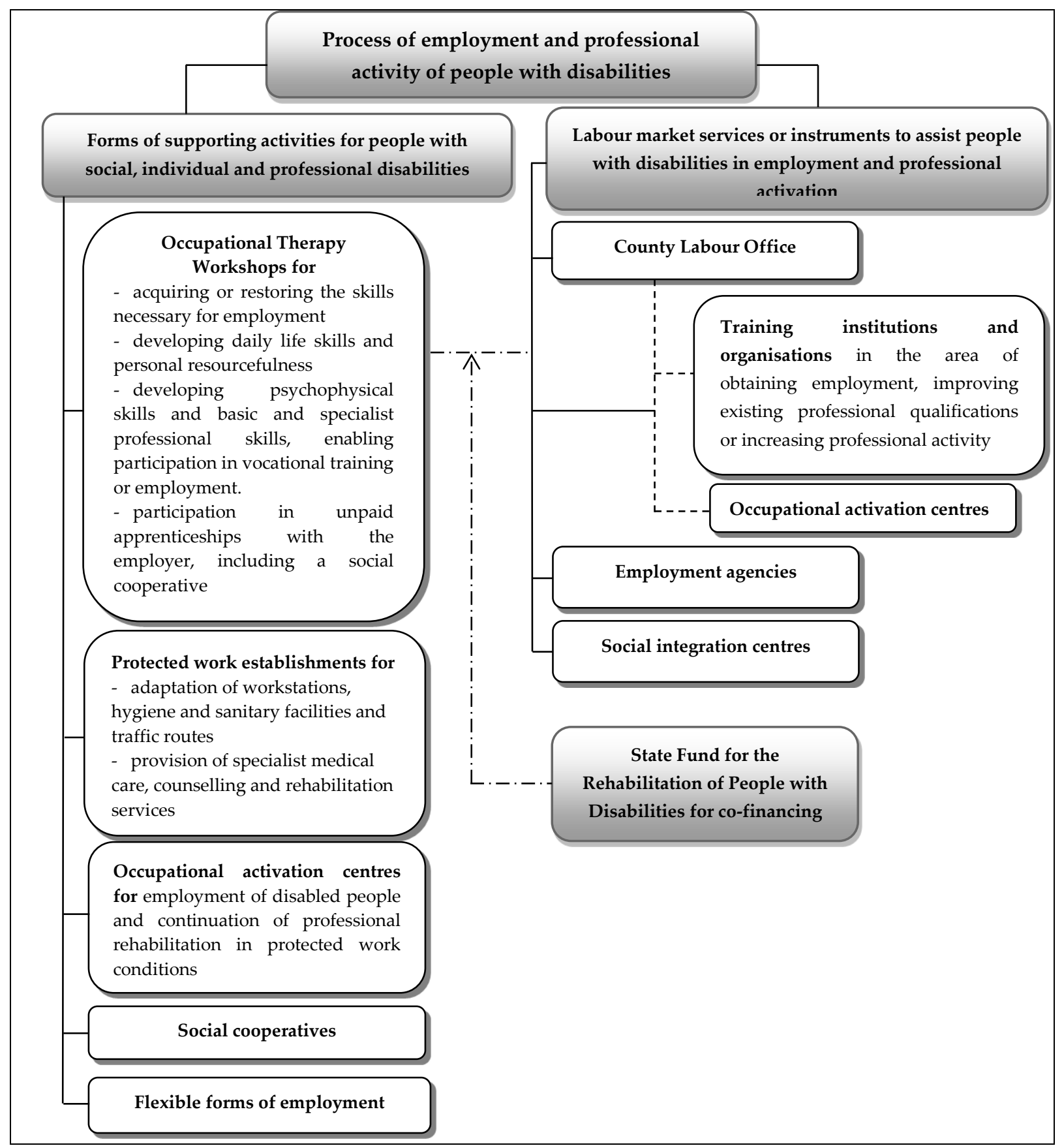

Fig. 1. Selected forms of activity supporting people with social, individual and professional disabilities. Source: own study based on legislation [36; 39; 40]

to solve problems of people with disabilities, specified by non-governmental organisations and local government units. The areas of key co-financing concern: support for disabled people in maintaining their independence and social and professional life, elimination or reduction of barriers concerning people with disabilities in social and professional life and in access to education, increasing the employment rate of people with disabilities and integration and activation [11]. Funding for the indicated tasks as well as other tasks resulting from the problems of the disabled are also co-financed by the European Social Funds (ESF). The Minister of Infrastructure and Development has developed a programme for financing or co-financing from ESF funds of projects in the field of equal opportunities and non-discrimination, including accessibility for people with disabilities [17]. In the programme entitled "Guidelines for the implementation of the principle of equal opportunities and nondiscrimination, including accessibility for people with disabilities within the framework of EU funds 
for 2014-2020" it indicated the possibility of funding tasks for people with disabilities, increasing the integration of employment, education and training [17].

The co-financing of the tasks indicated stimulates activity and fosters integration and employment of people with disabilities in the labour market. It requires improvement especially in the areas of individual and social problems of disabled people, with respect to:

- financial support for the education system, thus increasing access to education and vocational training [8, p. 69];

- financial support for disabled graduates of secondary schools in order to become independent after completing their education [15, p. 182];

- increasing the professional activity of people with disabilities in various forms of personal development, including the flexibility of the disabled person to adapt to the labour market environment [15, p. 182];

- teleworking market as a form of activity of people with disabilities in the open labour market [32, p. 239] and dissemination of other flexible forms of employment adapted to people with disabilities [19, p. 239];

- implementation of programmes supporting professional activity and employment of people with disabilities, due to the perception, communication, adaptation of workstations to people with disabilities by employers of the open labour market [24, p. 116]

- educational process, and in particular the options of e.g. distance learning and improving the guidance system for increasing interpersonal and market skills [19, p. 239];

- adaptation and improvement of the system of vocational guidance on employment of disabled people on the domestic and foreign markets [19, p. 239];

- capacity of information channels of local government units in terms of the implementation of tasks, solving problems of the disabled, functioning of vocational and social rehabilitation system, employment and professional activity [2, p. 294; 3, p. 317];

- interpersonal barriers of people with disabilities, which are characterized by withdrawal, passiveness, avoidance, and learned motivation to be less active, less efficient and integrated in the local environment [21, p. 365]

- modification and arrangement of the legal form of the system of disability identification [10, p. 24] and regulations on identification of disability in the countries of the European Union with respect to the status of a disabled person in the European Union [7, p. 181]

- system solutions concerning the assistant of a disabled person and job trainer in the field of social support and professional activation and employment of people with disabilities [22, p. 41].

\section{CONCLUSIONS}

In solving the above-mentioned problems presented in the literature, it is necessary to indicate the need to create a local support system, which, in the form of mutually dependent tasks, will affect the integration of people with disabilities and activity and employment in the labour market. The present solutions support people with disabilities by providing assistance in the area of statutory tasks. Undoubtedly, they are a proposal for tasks activating people with disabilities in the education and labour market, but they require adaptation of the tasks to the problems of everyday life of people with disabilities and problems of the local environment. People with disabilities are often unable to benefit from support due to the existence of difficulties in solving problems with reporting the degree and type of disability. Awareness of the existence of difficulties in solving problems reported in institutions or aid organisations results in a withdrawal attitude. This indicates the need for coordinated actions to support people with disabilities individually and socially and to define tasks to support families of people with disabilities and the local environment, which provides social and professional assistance. An important determinant influencing professional activity and employment of disabled people is to increase the number of aid activities in the area of solving local problems of disability and local promotion of disabled people in the context of social and professional expectations. 
Taking into consideration the realisation of the presented supporting tasks to satisfy individual, social and professional needs of people with disabilities, it is necessary to introduce improving elements concerning: creation of local aid processes for people with disabilities, which in the realization of support tasks will conduct an initial local diagnosis and determine supporting forms with indication of aid organisations, institutions and centres. It is also important to make the forms of support more flexible by taking decisions from the point of view of meeting local needs and expectations of people with disabilities and their families, and to extend the statutory aid tasks in the field of supporting professional activity and employment of people with disabilities on the international market. Developing and introducing new tasks and improving current directions of support will strengthen an integral part of social and professional life of people with disabilities and stakeholders. On the one hand, it will meet the needs and expectations of people with disabilities; on the other hand, it will change the image of people with disabilities and the social perception of disability in the local environment. Introduction of coordinated aid measures will equalise opportunities for people with disabilities in the area of social life, employment and activity in the labour market.

\section{REFERENCES}

[1] Barczyński A. Koszty zatrudniania osób niepetnosprawnych [Costs of employing people with disabilities]. Krajowa Izba Gospodarczo-Rehabilitacyjna, Warszawa, 2008. (in Polish)

[2] Barczyński A. Realne bariery wstrzymujące aktywizację zawodową niepełnosprawnych [Real barriers preventing professional activation of the disabled]. In: Identyfikacja przyczyn niskiej aktywności zawodowej osób niepetnosprawnych [Identifying the causes of low professional activity of people with disabilities]. Warszawa, 2008, 43-52. (in Polish)

[3] Chorążuk J. Aktywizacja zawodowa osób niepełnosprawnych w świetle badań samorządów powiatowych, samorządów gminy oraz osób niepełnosprawnych [Professional activation of people with disabilities in the light of research of county self-governments, commune self-governments and the disabled]. In: Barczyński A., Strzałkowki M. (Red.) Społeczne korzyści zatrudniania osób niepetnosprawnych. Materiaty konferencyjne. [Social benefits of employing people with disabilities. Conference materials]. Krajowa Izba Gospodarczo - Rehabilitacyjna, Warszawa, 2008. (in Polish)

[4] Czarnecki K.M., Pietrulewicz B. Leksykon Profesjologiczny [Profesiological Lexicon]. Wyższa Szkoła Humanitas, Sosnowiec, 2010. (in Polish)

[5] Czarnecki K.M. Profesjologia. Nauka o zawodowym rozwoju człowieka [Profesiology. Science of professional development of man]. Wyższa Szkoła Humanitas, Sosnowiec, 2010. (in Polish)

[6] Duliniec E. Postępowanie nabywców towarów konsumpcyjnych w krajach o gospodarce rynkowej: analiza marketingowa [Conduct of buyers of consumer goods in market economy countries: marketing analysis]. Monografia i Opracowanie SGPiS, 204. Szkoła Główna Planowania i statystyki, Warszawa, 1986. (in Polish)

[7] Garbat M. Możliwości migracji zarobkowej osób z niepełnosprawnościami chronionego rynku pracy w Unii Europejskiej [Possibilities of economic migration of persons with disabilities in the protected labour market in the European Union]. In: Borek J., Olszewski M. (Red.) Aktywizacja zawodowa osób z orzeczona niepetnosprawnościa [Professional activation of people with certified disability]. Uniwersytet Technologiczno - Humanistyczny, Radom, 2015. (in Polish)

[8] Garbat M., Paszkowicz M.A. Niepełnosprawność jako przyczyny wykluczenia z rynku pracy [Disability as a reason for exclusion from the labour market]. In: Paszkowicz M.A., Ślusarz B. (Red.) Nierówności społeczne a rozwój gospodarczy [Social inequalities versus economic development]. Zeszyty Naukowe Polskiego Towarzystwa Ekonomicznego w Zielonej Górze, Zielona Góra, 2016. (in Polish)

[9] Grzegorzewska I. Osoba niepełnosprawna w środowisku rodzinnym - znaczenie potrzeb akceptacji [Disabled person in a family environment - the importance of acceptance needs]. In: Ochonczenko H., Nowicka A. (Red.) Potrzeby osób niepetnosprawnych w warunkach globalnych przemian społecznogospodarczych [Needs of people with disabilities in the conditions of global socio-economic changes]. Impuls, 
Kraków, 2000. (in Polish)

[10] Grzywacz R. System orzekania o niepełnosprawności w Polsce [System of declaring disability in Poland]. In: Borek J., Olszewski M. (Red.) Aktywizacja zawodowa osób z orzeczona niepetnosprawnościa [Professional activation of people with certified disability]. Uniwersytet Technologiczno - Humanistyczny, Radom, 2015. (in Polish)

[11] Available at: https://www.pfron.org.pl/o-funduszu/programy-i-zadania-pfron/programy-i-zadaniareal/pilotazowy-program-prac/komunikat-procedury-realizacji-pilotazowego-programu-pracaintegracja/ (in Polish)

[12] Janocha W. Rodzina z osoba niepetnosprawna w społecznym systemie wsparcia [Family with a disabled person in the social support system]. Jedność, Kielce, 2009. (in Polish)

[13] Kacperczyk A. Wsparcie społeczne w instytucjach opieki paliatywnej i hospicjum [Social support in palliative care institutions and hospice]. Wydawnictwo Uniwersytetu Łódzkiego, Łódz, 2006. (in Polish)

[14] Kotler P. Marketing - analiza, planowanie, wdrażanie i kontrola [Marketing - analysis, planning, implementation and control]. Wydawnictwo Felberg SJA, Warszawa. 1999. (in Polish)

[15] Loska M. Kształcenie ponadgimnazjalne dla młodzieży niepełnosprawnej - oczekiwania i niepokoje [Upper secondary education for disabled youth - expectations and concerns]. In: Szczupał B. (Red.) Młodzież niepetnosprawna - szanse i zagrożenia w aktualnej rzeczywistości społecznej [Disabled youth opportunities and threats in current social reality]. Wydawnictwo Naukowe Akapit, Kraków, 2005. (in Polish)

[16] Łobacz E. Rola ośrodka wczesnej interwencji we wspomaganiu dziecka niepełnosprawnego wzrokowo i jego rodziny [Role of early intervention centre in aiding visually disabled children and their family]. In: Ochonczenko H., Nowicka A. (Red.) Potrzeby osób niepetnosprawnych w warunkach globalnych przemian społeczno-gospodarczych [Needs of people with disabilities in the conditions of global socio-economic changes]. Impuls, Kraków. 2000. (in Polish)

[17] Minister Infrastruktury i Rozwoju. Wytyczne w zakresie realizacji zasady równości szans i niedyskryminacji, $w$ tym dostępności dla osób z niepetnosprawnościami oraz zasady równości szans kobiet i mężczyzn w ramach funduszy unijnych na lata 2014-2020 [Guidelines on the implementation of the principle of equal opportunities and non-discrimination, including accessibility for people with disabilities, and the principle of equal opportunities for women and men under EU funds for 2014-2020]. Warszawa 8 maja 2015 MIiR/H 20142020/16(01)/05/2015. (in Polish)

[18] Ochonczenko H. Potrzeba własnej wartości i jej rola w funkcjonowaniu osób niepełnosprawnych [Need for self-worth and its role in the functioning of people with disabilities]. In: Ochonczenko H., Nowicka A. (Red.) Potrzeby osób niepetnosprawnych w warunkach globalnych przemian społeczno-gospodarczych [Needs of people with disabilities in the conditions of global socio-economic changes]. Impuls, Kraków, 2000. (in Polish)

[19] Ochonczenko H. Uwarunkowania aktywności zawodowej osób niepełnosprawnych (raport z badań) [Determinants of the professional activity of people with disabilities (study report)]. In: Baczyński A., Strzałkowski M. (Red.) Społeczne korzyści zatrudniania osób niepetnosprawnych. Materiał konferencyjny [Social benefits of employing people with disabilities. Conference materials]. Krajowa Izba GospodarczoRehabilitacyjna, Warszawa, 2008. (in Polish)

[20] Ochonczenko H. Znaczenie edukacji w procesie aktywizacji zawodowej osób zagrożonych wykluczeniem społecznym w kontekście doświadczeń projektu AKIS [Importance of education in the process of professional activation of people at risk of social exclusion in the context of the experience of the AKIS project]. Problemy profesjologii, 2 (2017), 87-102. (in Polish)

[21] Olszewska B. Pokonywanie barier $w$ relacjach interpersonalnych studentów z niepełnosprawnością i bez niepełnosprawności $\mathrm{w}$ perspektywie przyszłej integracji zawodowe [Overcoming barriers in interpersonal relations of students with and without disabilities in the perspective of future professional integration]. In: Baczyński A., Strzałkowski M. (Red.) Społeczne korzyści zatrudniania osób niepetnosprawnych. Materiat konferencyjny [Social benefits of employing people with disabilities. Conference materials]. Krajowa Izba Gospodarczo-Rehabilitacyjna, Warszawa, 2008. (in Polish)

[22] Olszewski M. Aktywizacja zawodowa i społeczna osób niepełnosprawnych w projektach finansowanych z Europejskiego Funduszu Społecznego na przykładzie usług agenta i trenera pracy [Professional and social activation of people with disabilities in projects financed from the European 
Social Fund on the example of the services of a job agent and trainer]. In: Pietrulewicz B., Paszkowicz M.A. (Red.) Wybrane zagadnienia aktywności zawodowej człowieka na rynku pracy [Selected issues of human professional activity in the labour market]. Wydawnictwo Naukowe Polskiego Towarzystwa Profesjologicznego, Zielona Góra, 2015. (in Polish)

[23] Paszkowicz M.A. Zaspokojenie potrzeb osób niepełnosprawnych [Meeting the needs of people with disabilities]. In: Aktywizacja zawodowa osób niepetnosprawnych, nr 3(3). [Professional activation of people with disabilities]. Krajowa Izba Gospodarczo - Rehabilitacyjna, Warszawa, listopad, 2005. (in Polish)

[24] Paszkowicz M.A. Systemy i programy zatrudnienia osób niepełnosprawnych [Employment systems and programs for people with disabilities]. In: Baczyński A., Strzałkowski M. (Red.) Społeczne korzyści zatrudniania osób niepetnosprawnych. Materiat konferencyjny [Social benefits of employing people with disabilities. Conference materials]. Krajowa Izba Gospodarczo-Rehabilitacyjna, Warszawa, 2008. (in Polish)

[25] Plewka Cz. Człowiek w całożyciowym rozwoju zawodowym - zarys monograficzny wzbogacony ilustracja własnych badan empirycznych [Man in lifelong professional development - a monographic outline enriched by presentation of own empirical research]. Wydawnictwo Uczelniane Politechniki Koszalińskiej, Koszalin, 2016. (in Polish)

[26] Dz.U. 2015 poz. 926. Regulation of the Minister of Labour and Social Policy of 11 June 2015 on defining the type of tasks of the county which can be financed from the funds of the State Fund for Rehabilitation of Persons with Disabilities. Available at: http://prawo.sejm.gov.pl/isap.nsf/DocDetails.xsp?id=WDU20150000926 (in Polish)

[27] Dz.U. 2007 nr 230 poz. 1696. Regulation of the Minister of Labour and Social Policy of 15 November 2007 on rehabilitation holidays (Journal of Laws No. 230, item 1694). Available at: http://prawo.sejm.gov.pl/isap.nsf/DocDetails.xsp?id=WDU20072301696 (in Polish)

[28] Dz.U. 2013 poz. 1565. Regulation of the Minister of Health of 6 December 2013 on the list of medical devices issued on order. Pursuant to Article 38, section 4 of the Act of 12 May 2011 on the Reimbursement of Medicines, Foodstuffs for Special Nutritional Purposes and Medical Devices (Journal of Laws No. 122, item 696, as amended) Warsaw 17 December 2017. Available at: http://prawo.sejm.gov.pl/isap.nsf/DocDetails.xsp?id=WDU20130001565 (in Polish)

[29] Stownik języka polskiego, Tom trzeci R-Z [Polish Dictionary, volume three R-Z]. Państwowe Wydawnictwo Naukowe, Warszawa, 1981. (in Polish)

[30] Swereda D. Programy edukacyjne i działania polskich uczelni wyższych na rzecz osób niepełnosprawnych [Educational programs and activities of Polish universities for the benefit of people with disabilities]. In: Ochonczenko H., Nowicka A. (Red.) Potrzeby osób niepetnosprawnych w warunkach globalnych przemian społeczno-gospodarczych [Needs of people with disabilities in the conditions of global socioeconomic changes]. Impuls, Kraków, 2000. (in Polish)

[31] Szczęsna A., Jadkowski K. Poczucie wsparcia u wychowanków dzieci i młodzieży niepełnosprawnych a obraz psychologiczny podopiecznych [Sense of support in children and adolescents with disabilities versus the psychological image of charges]. In: Ochonczenko H., Nowicka A. (Red.) Potrzeby osób niepetnosprawnych $w$ warunkach globalnych przemian spoteczno-gospodarczych [Needs of people with disabilities in the conditions of global socio-economic changes]. Impuls, Kraków, 2000. (in Polish)

[32] Szczupał B. Telepraca jako forma zatrudnienia młodzieży niepełnosprawne [Telework as a form of employment for disabled youth]. In: Szczupał B. (Red.) Młodziė̇ niepełnosprawna - szanse i zagrożenia [Disabled youth - opportunities and threats]. Wydawnictwo Naukowe Akapit, Kraków, 2005. (in Polish)

[33] Urbanowicz U. Burda-Świerz K. Dostęp osób niepełnosprawnych do opieki zdrowotnej i rehabilitacyjnej $\mathrm{w}$ dobie globalnych przemian społeczno-gospodarczych [Access of people with disabilities to health and rehabilitation care in the era of global socio-economic changes]. In: Ochonczenko H., Nowicka A. (Red.) Potrzeby osób niepetnosprawnych w warunkach globalnych przemian spoteczno-gospodarczych [Needs of people with disabilities in the conditions of global socio-economic changes]. Impuls, Kraków, 2000. (in Polish)

[34] Dz.U. 2016 poz. 1828. Act on Social Employment (Journal of Laws 2016.0.1828) concerns point 5. Available at: http://prawo.sejm.gov.pl/isap.nsf/DocDetails.xsp?id=WDU20160001828 (in Polish)

[35] Dz.U. 2004 nr 99 poz. 1001. Act of 20 April 2004 on Employment Promotion and Labour Market Institutions (OJ 2017, items 1065, 1292, 1321, 1428, 1543, 2371, 2494, 2018, items 107, 138, 650, 730, 858, 114). Available at: http://prawo.sejm.gov.pl/isap.nsf/DocDetails.xsp?id=WDU20040991001 (in Polish) 
[36] Dz.U. $1991 \mathrm{nr} 80$ poz. 350. Act of 26 July 1991 on Personal Income Tax (OJ 1991 No. 80 item 350). Available at: http://prawo.sejm.gov.pl/isap.nsf/DocDetails.xsp?id=wdu19910800350 (in Polish)

[37] Dz.U. $1997 \mathrm{nr} 123$ poz. 776. Act of 27 August 1997 on Vocational and Social Rehabilitation and Employment of Disabled People (OJ 2018, items 511, 1000, 1076). Available at: http://prawo.sejm.gov.pl/isap.nsf/DocDetails.xsp?id=WDU19971230776 (in Polish)

[38] Dz.U. 2004 nr 99 poz. 1001. Act of 20 April 2004 on Employment Promotion and Labour Market Institutions and Act on Social Employment (OJ 2016.0.1828), Act of 12 March 2004 on Social Aid (OJ 2017.1769 as amended, OJ 2018.700). Available at: http://prawo.sejm.gov.pl/isap.nsf/download.xsp /WDU20040991001/T/D20041001L.pdf (in Polish)

[39] Zamkowska A. Nauczanie we współczesnym nurcie na przykładzie Hiszpanii [Teaching in the modern trend on the example of Spain Ochonczenko H., Nowicka A. (Red.) Potrzeby osób niepetnosprawnych w warunkach globalnych przemian społeczno-gospodarczych [Needs of people with disabilities in the conditions of global socio-economic changes]. Impuls, Kraków, 2000. (in Polish)

Address: Anna Ziętek, Pedagogical and Technical College, Powstańców Wielkopolskich Str., Konin 62-500, Poland.

E-mail: annazietek@wp.pl

Received: 02.01.2020; revised: 12.03.2020.

Зітек Анна. Значення психолого-педагогічного супроводу в житті людей 3 обмеженими мождивостями. Журнал Прикарпатського університету імені Василя Стефаника, 7 (1) (2020), 93-101.

У статті представлено актуальність та сутність проблеми психолого-педагогічного супроводу в житті людей з обмеженими мождивостями. Вказано, що для адаптації підтримки індивідуальних потреб людей з інвалідністю необхідно запровадити елементи, що покращують систему психологопедагогічної та соціальної допомоги. Обгрунтовано завдання та значення окремих факторів системи підтримки людей з обмеженими мождивостями як на індивідуальному рівні, так і в соціальнопрофесійному середовищі. Представлено чинні законодавчі рішення, які спрямовані на стимудювання професійної діяльності та інтегрування осіб з інвалідністю та їхніх сімей у соціальне та освітне середовище. У роботі висвітлено авторські ідеї щодо вдосконалення системи "вирівнювання" можливостей для реалізації осіб з особливими потребами у соціальному та професійному житті. Наголошено також особливостях створення належних умов для залучення таких осіб до професійної діяльності, забезпечення їх зайнятості на ринку праці. Здійснено спробу оцінити чинники, що визначають ефективність системи психолого-педагогічного й соціального супроводу, з урахуванням реалізованих програм допомоги, дотацій, пільг та завдань організацій та установ, що підтримують людей з обмеженими мождивостями у соціально-професійному аспекті. Автором акцентовано на потребі підготовки, підвищення кваліфікації та адаптації до відкритого ринку праці осіб 3 інвалідністю. Особливе значення має також соціальне сприйняття інвалідності. Аюди з обмеженими мождивостями мають підвищені потреби до безпеки, незалежності чи доступності до соціальної інфраструктури. Це значною мірою залежить від підтримки дюдей з обмеженими мождивостями у родині, їх опікунів та установ чи організацій, які надають відповідну допомогу, в т.ч. закдадів освіти, реабілітації чи працевлаштування. У статті представлені заходи, які є домінантними для пошуку нових рішень задля поліпшення адаптаційних мождивостей людей з особливими потребами до існуючий реалій.

Кдючові слова: професійна підготовка, освіта, професійна діяльність, ринок праці, професійне навчання, особи з інвалідністю, психолого-педагогічний супровід людей з інвалідністю. 